THURSDAY, JANUARY 15, I89I.

\section{THE INTERNATIONAL CONGRESS OF HYGIENE AND DEMOGRAPHY.}

I

NTERNATIONAL Congresses on Hygiene have been held at about two years' interval in various capitals of Europe since the year 1877 . The first was held at Brussels under the especial auspices of the King of the Belgians, and was accompanied by an Exhibition of Sanitary Appliances. After the second of these Congresses, it was decided to associate with the Hygienic Congress one on the cognate subject of demography, which may be defined as the science of statistics applied to the social well-being of the people. The Congress which will assemble in London in August next will be the seventh on hygiene, and the fifth on demography. The last Congress was held at Vienna under the auspices of the Crown Prince Rudolf in 1887 . It was then settled that the next Congress was to be held in London, and the year I891 was selected; because the organizers of the French Exhibition had already announced Congresses on cognate subjects to be held in 1889 in Paris.

The object of these Congresses is to promote the interchange of views between those persons in various countries who have studied the subjects of hygiene and demography, especially with respect to their bearing upon the welfare of the people, as well as upon the intercourse between nations. So far as regards hygiene, in these days of rapid transit, the sanitary condition of any one nation is more than ever a matter of concern to its neighbours, and assemblies of delegates of different nationalities for the discussion of hygienic problems, and the comparison of hygienic methods, are of great importance. For instance, among the most prominent of the subjects which have been treated at these Congresses, has been that of quarantine. England has for some time maintained the view that the efficient sanitation of a country, and especially of seaport towns, is a better safeguard against the importation of cholera than any measures of quarantine. No doubt England has been somewhat at a disadvantage in maintaining its argument, because, whilst it has attended carefully to the sanitation of this country, it has allowed the sanitation of India, which is the birthplace of cholera, to remain in a disgraceful condition. Yet for all that, whilst at the earlier Congresses the views of England upon this important question were entirely set aside, at the last Congress the discussions which had arisen at previous Congresses had so permeated the minds of students of hygiene on the Continent, that it was generally conceded at the Vienna Congress that the enforcement of the laws of health amongst the population of a country was a far more effective measure for preventing the spread of cholera in the country than any measures of quarantine. We may therefore hope that the discussions which will take place at the Congress in London will still further awaken Continental nations to the advantages of sanitation in contradistinction to the absurdities of quarantine; and will also be a means of compelling our Indian authorities to bestir themselves to remove the stigma which now attaches to India of affording a prominent instance of defective sanitation.

No. I IO7, vol. 43]
In addition to this, numerous social questions intermixed with hygiene now press for a solution, which can be arrived at only after discussion. The term demography is new in this country. Dr. Mouat, the eminent President of the Statistical Society, has, in his late very able address to the Society, given an interesting explanation of the origin of the term. The following extract may advantageously be given here :-

"The term ' demography' is not to be found in any of our dictionaries, even of tolerably recent date, and in France is only contained in the great work of Littré, who denominates it ' a didactic expression descriptive of peoples as regards the population in relation to ages, professions, dwellings, \&c.,' and he also adopts the definition of Quetelet, that it is 'the natural history of society.' The appellation appears to have been first employed by M. Galliard in his 'Elements of Human Statistics, or Demography,' published in 1855 . The first President of the Society, the late Dr. Bertillon, treated it as dealing with the inner life of the social bodies which form a people (births, marriages, deatbs, migrations, \&c.), but only in their collective influence, of which it measures the powers of the parts or of the whole, without meddling with biological proceedings, which distinguish it from physiology."

Dr. Bertillon regarded England as the real home of demography, as it surpassed all other nations in the incomparable richness of its demographic inquiries, and in the unbroken continuity of its published returns.

The subjects which will be open to discussion in the Congress may be classed under the following general heads:-(I) The prevention of communicable diseases, as, for instance, (a) whether sanitation or quarantine is most efficient against cholera ; $(b)$ how the spread of disease from milk and from water can be checked; $(c)$ the relation which tuberculosis and other diseases in animals bear to mankind; (d) vaccination, the prevention of leprosy, rabies, and such like contagious diseases; $(e)$ the effect of soil on communicable diseases; $(f)$ disinfection and disinfectants. (2) The science of bacteriology in relation to communicable diseases. In connection with this subject an exhibition of microscopic and cultivation specimens would be arranged. (3) Industrial questions, as, for instance, the regulation of industrial occupations from a health point of view, including the length of hours of labour in different occupations, the influence of dwellings upon labour, and the effect of large cities on the health of the population; the influence of the health condition of the people, and the effect of different sorts of food and of wages upon the efficiency of labour. (4) The hygiene of infancy and childhood, as, for instance, protection and insurance of infant life; school hygiene, including length of hours of study, nature of studies, and the effect of physical training; school buildings and their accessories, and other educational questions bearing on health. (5) The hygiene of houses and towns, including questions of width of streets, height of buildings, air space round houses, house construction, water supply, river pollution, drainage, treatment of refuse, disposal of the dead. (6) State hygiene, or the duty of the Government towards the nation in regard to health, and the machinery necessary for exercising that duty; the duties of communities towards each other in regard to questions of health, and towards the individuals of which they are composed; the 
laws for notification and isolation of disease; the status and education of medical officers of health and of sanitary inspectors.

In consequence of the wide scope covered by these subjects, it is proposed that the work of the Congress shall be divided between ten Sections. The order in which they will stand is not finally settled, but they may be briefly summarized as follows:-(I) Demography, which necessarily involves questions of industrial health; (2) communicable diseases ; (3) bacteriology ; (4) diseases of animals in relation to man ; (5) hygiene of infancy and childhood; (6) engineering in relation to hygiene; (7) architecture in relation to hygiene ; $(8)$ chemistry in relation to hygiene ; (9) military and naval hygiene ; and last, but not least important, (IO) the functions of the State in relation to hygiene.

The Prince of Wales, who has so deep a personal interest in all matters relating to the well-being of the community, at once acceded to the request made to him to accept the post of President of the Congress ; and the British Presidents and other officers of Sections will be among the most eminent men in their several departments of knowledge. Upon them will lie the duty of organizing the work of the several Sections before the Congress meets. They will be supplemented at the meeting of the Congress by foreign or colonial and Indian representatives, distinguished in the several branches of science included in the programme. It may be mentioned that above 2000 members, exclusive of representatives from Great Britain, attended the Vienna Congress ; and it is anticipated that the Congress in London will attract at least an equal number of persons from foreign countries, because Great Britain affords so many examples of im. portant sanitary works, as well as of institutions having the preservation or restoration of health as their main object.

The expenses of correspondence and other matters connected with the organization of the Congress are so large that appeal is made to those interested in the subjects to be discussed to aid the work by moderate contributions.

\section{GEOLOGICAL TEXT-BOOKS.}

Class-Book of Geology. By Archibald Geikie, F.R.S. Second Edition. (London: Macmillan and Co., I89o.) Elementary Geology. By Charles Bird, B.A., F.G.S. (London: Longmans, Green, and Co., I89o.)

$\triangle \mathrm{LL}$ who care for geology, teachers and students \& especially, will hail with delight the appearance of a second edition of Dr. A. Geikie's " Class-book." All the more that it may now be had at less than one-half the cost of the first edition. Such a substantial reduction in the price of a scientific book is a piece of liberality and farseeing policy which it could be wished were more common. Too often, when a rapid sale of such a work has proved that its value is appreciated and its success assured, there seems to be a feeling that its established reputation may be relied upon to ensure a demand for it in the future equal to that of the past, and that it will be quite safe to keep up its price. But no such purely mercantile views have prevailed here, and we may feel sure that both No. IIO7, VOL. 43] publishers and author have been actuated first of all, in the bold step they have taken, by a wish to promote the extension of knowledge by placing within the reach of as many as possible a work so well got up, so admirably illustrated, and so full of matter presented in an eminently readable form. And there can be little doubt that this disinterested conduct will reap the reward it deserves. Many a teacher will bear me out that the book has been a universal favourite. Students who would not put up with the dry compendium of the normal text-book have been won over by its attractive style; and even those earnest workers, who despise or excuse the absence of literary elegance, have found their labours lightened and have felt an added pleasure when their first introduction to geology has been through the medium of this class-book. One thing only prevented its being adopted far and wide as a text-book in the school and lecture-room. Now that obstacle is removed, it is sure to come into more and more extensive use ; and it may be confidently predicted that a rapidly increasing sale will soon recoup those concerned for $y$ temporary loss that their generous treatment of the public may at first occasion.

It is the conviction that it will not be long before a second opportunity for revision presents itself, and a wish to give, if it can be done, some help towards making so excellent a book more perfect still, that embolden me to be critical, and to point out a few minor points which seem capable of emendation; and I take this course with the less hesitation, and with no fear of being misunderstood, because I have endeavoured, in a previous notice of the first edition, to do justice to the many excellences of the work and to explain its scope.

I cannot say that the account of the formation of "flood plains," on p. 39, quite commends itself to my mind. The author postulates the existence of an alluvial flat, over which sand and silt are deposited during floods, but he does not explain how this flat is produced. Possibly the required explanation may be found in his "Physical Geography," which he recommends should be read in connection with the present work. If this be so, a reference to the passage required would be useful : indeed, wherever the one book is required for the elucidation of the other, it might be well to call attention to the fact in a note. The impartial and judicious blending of Darwin's and Murray's views on the growth of coral reefs is much to be commended. If we take into account the vast number of cases in which minerals occur without any external crystallized shape, it seems hardly safe to say that they have " in most cases a certain geometrical form" (p. 123). But the mineralogical sketch seems capable of improvement in more than one direction. The using "sides" and "faces" as if they were convertible terms, in the description of rock-crystal on p. 124, is apt to engender confusion of thought. In the account of felspars there is no mention of their cleavages, a property so often of practical value in distinguishing them from quartz, and a property far more easily recognized by the beginner than their monoclinic and triclinic crystallization. In some cases-mica, for instance-there is no mention of hardness, where that is a character useful in identification. It would not be fair to blame a geologist for the definition of the systems of crystallization given in the book before us, as long as it still survives in treatises 